\title{
State school as an entity providing Catholic Religious Education?
}

In many countries religious education takes place within the public education system. At the same time there is a debate on legitimacy of such a solution. Increasingly, there are voices calling for the removal of religious education from public schools. Particular pressure is exerted on the confessional model of religious education, which taught religious truths of faith, liturgy, moral principles, of one religious community. This article is a polemic with these opinions. It shows the arguments for the presence of Catholic religious education in public school. These arguments relate primarily to non-religious function of teaching religion, such as the transmission of objective knowledge, forming social attitudes and help in finding the meaning of life. Even with these reasons, Catholic religious education should take place in the state education system.

Key words: Religious Education, religious instruction, religion in the state education system.

\section{Introduction}

The vast majority of countries, particularly in Europe, are currently subject to very dynamic secularization processes, which applies particularly to Christianity and the Catholic Church. More and more often, people contest the truth of faith and the moral principles preached by this Church. Their position is taken over by two main principles of postmodernism: absolute pluralism and uncritical tolerance. 
At the same time, confessional teaching of religion is still conducted in many countries and it is done in public schools that are established and financed by a secular state. There are many opponents of such a solution, arguing that the only entity for such an education should be the Church. The main argument brought up for eliminating confessional religious education in state schools is the alleged realization of only religious purposes, thereby of no benefit to the state. In consequence, postulates are made for the Church to take full responsibility for religious education in the confessional perspective. Thus a very topical question remains, whether and why should a public school remain an entity of Catholic religious education. This paper shall make an attempt to provide an answer on this issue. The analysis of the problem shall firstly offer an explanation of the concept of confessional Catholic religious education, and next, a presentation of arguments, in favour of conducting such lessons in public schools.

\section{The essence and Types of Confessional Catholic Religious Education}

The confessionalism of teaching religion within the public educational system involves, above all, the leading role of the religious community in its programming. Thus, the contents of confessional teaching of religion are most often the truths of faith, liturgy, moral principles, and prayers of a particular religious community. In the case of the Catholic Church these contents comprise the entire deposit of the catholic faith, contained in the Bible and Traditions of the Church, systematically framed in the Catechism of the Catholic Church ${ }^{1}$. Such a perspective does not, however, imply a complete omission of other religions or denominations, but those issues are shown from the perspective of the Catholic Church. Consequently, confessional teaching of religion is characterized by a significant role played by the Church in preparation curriculum and textbooks, as well as in choosing persons to teach the subject, by granting a missio canonica ${ }^{2}$. Therefore, in practice, the state has no influence on the contents of teaching religion, as well as the personnel assignments for teaching these classes. However, confessional teaching of religion includes various different models. The formation and information model (learning from religion and learning about religion) may both be considered as the main two.

$1 \quad$ Katechizm Kościoła Katolickiego, Watykan 1992.

2 P. Mąkosa, Confessional and catechetical nature of religious education in Poland, „The Person and the Challenges", vol. 5 (2015), no. 2, p. 60. 
In some countries, teaching the Catholic religion is not only of a confessional nature, but also strictly formative, catechetical (e.g. Catechetics in Poland and $\mathrm{Croatia}^{3}$ ). This means that during the lesson, not only is knowledge transferred on the Catholic faith, but also attempts are made at shaping religious attitudes such as: personal acceptance of the laws of faith, participation in the liturgy and sacramental life, acceptance of Catholic moral principles, and introduction to the practice of prayer. From this perspective, the teaching of religion is very similar to religious instruction, and its objective is to lead "not only to meet Christ, but to have a communion, or perhaps even a more emotionally intimate relationship with Him" ${ }^{4}$. Understood in this way the teaching of religion strives to complete all tasks of catechesis, i.e. the development of an understanding of faith, liturgical education, moral formation, education for prayer, education for living in a community, introduction to the mission ${ }^{5}$. The formative model of teaching religion is thus a form of catechesis, and for this reason may only be realized in environments, where all, or at the least, a vast majority of students participating in the lesson, are at the same time, active Catholics. From an ecclesial point of view, this would be an optimal situation. However, it is currently very difficult to attain such a state. Even in the most Catholic countries, students participating in lessons on religion at a public school exhibit various levels of religiousness, include members of other religions and denominations, as well as atheists. Therefore, more and more often discussions are held pertaining to a change in the concept of religious education. Most often, however, no attempts are made to resign from its formative scope, but instead of religious instruction, emphasis is put on evangelization. Its goal is no longer the deepening of faith, as much as sparking it. Still, however, the main purpose for such an education is confessional in nature.

$3 \quad$ Cf. Z. Nosowski, Lekcje religii w szkołach publicznych państw europejskich, [in:] Szkota czy parafia? Nauka religii w szkole w świetle badań socjologicznych, K. Kiciński, K. Koseła, W. Pawlik eds., Kraków 1995, p. 11-12; R. Chałupniak, Konfesyjność nauczania religii. Zarys problematyki, „Paedagogia Christiana” 3:2000, no. 2(6), p. 31-51; P. Mąkosa, Wspótczesne ujęcia nauczania religii w europejskim szkolnictwie publicznym, „Roczniki Pastoralno-Katechetyczne”, 58 (2011), 3, p. 123-136.

4 Jan Paweł II, Adhortacja apostolska „Catechesi tradendae”. Watykan 1979, no 5; Kongregacja do spraw Duchowieństwa, Dyrektorium Ogólne o Katechizacji, Watykan 1997, no. 80.

$5 \quad$ Kongregacja do spraw Duchowieństwa, Dyrektorium Ogólne o Katechizacji, Watykan 1997, no. 85-86. 
In some countries, Catholic religious education is realized in accordance with an informative model (e.g. Italy and Germany). It consists, first and foremost, of transferring objective knowledge about Christianity and the Catholic Church, as well as its relation to other religions. The purpose for such religious education is to provide knowledge about the religion, which had a significant impact on shaping the culture of the country, and is still impossible to understand without referring to Christianity and the Catholic Church. Catholics, members of other Christian denominations, members other religions, and atheists are natural participants in confessional religion lessons in the informative scope ${ }^{6}$. Within the informative model, functions are implemented mainly of teaching and upbringing. The realization of the function of initiation into Christianity is deemed to be an exclusive task of the church community.

After outlining the identity of Catholic religious education, it is worth readdressing the question posed in the introduction: should state school remain a community providing this type of education, particularly in the formative model? In the progressively more secularized societies, the answer to this question is not that obvious. While searching for an answer to this question it is worth consider whether and to what extent Catholic religious education is compatible with the educational expectations of the state. Presented herein below shall be three areas of impact of religious education which may provide an answer to this question: the transfer of knowledge, formation of social attitudes and help in finding the meaning of life.

\section{The Transfer of Knowledge in Catholic Religious Education}

One of the most important functions of religious education is to search for the truth and to transfer objective knowledge ${ }^{7}$. Of course, this function in the confessional perspective is realized not so much with regards to general knowledge as to religious knowledge, and is aimed at constructing intellectual grounds for faith. It is, however, beyond doubt, that at least the basic knowledge about Christianity and Catholicism, is part of a canon, which should be known to each educated person. In the European context, knowledge of this kind applies to the foundation of the entire continent, as well as the various

$6 \quad$ Cf. R. Chałupniak, Wychowanie religijne w szkołach europejskich, [in:] Wybrane zagadnienia $z$ katechetyki, J. Stala ed., Tarnów 2003, p. 188-189.

$7 \quad$ P. Tomasik, Religia $w$ dialogu z edukacja, Warszawa 2004, p. 334. 
states therein. For many countries, it is impossible to understand their history and culture without appropriate knowledge of Christianity and Catechetics the Catholic Church. It is therefore necessary to supply knowledge not only on the truths of Catholic faith, but also of historical events, Christian architecture, art and music. Without such knowledge, a person would be alienated in the European society. They would understand neither its foundations and history, nor its current problems.

For the above reasons, lessons at schools include discussions on numerous historical issues. These include e.g. such matters as: the civilizations of Mesopotamia (Babylonian and Assyrian); the history of ancient Egypt and Israel, the beginning and development of Christianity, its contribution to European development etc. Attending religion lessons at school therefore, provides the students with additional knowledge of history. A similar correlation is also present with regards to other subjects, e.g. music, fine arts, or geography ${ }^{8}$. During religion classes, discussions are held concerning such matters as e.g. Christian music and art, as well as the geographical location of Israel and Palestine ${ }^{9}$.

The transfer of knowledge about Christianity and the Catholic Church is conducted in connection with other fields of knowledge also for that purpose of shaping an integral vision of the world, free of juxtaposing such realities as faith and mind, religion and science, or the Church and the world ${ }^{10}$. For this reason, the Catholic Church is of the opinion that "teaching religion in schools should be viewed as a subject requiring the same level of organization as other subjects, and not as an addition, but an element of necessary, interdisciplinary dialogue" 11 .

The transfer of knowledge is directly included in the basic goals of the state school system, and the beneficiaries of participation in

$8 \quad$ Konferencja Episkopatu Polski, Podstawa Programowa Katechezy, Kraków 2010, p. 60-68; Cf. P. Tomasik, Religia $w$ dialogu z edukacja, Warszawa 2004, p. $296-328$.

9 Komisja Wychowania Katolickiego Konferencji Episkopatu Polski, Program Nauczania Religii Rzymskokatolickiejw Przedszkolach i Szkołach, Kraków 2010, p. 110-117.

10 G. Lange, Konfesyjna nauka religii $w$ publicznej szkole zsekularyzowanego społeczeństwa, „Analecta Cracoviensia” 23 (1991), p. 241; See K. Misiaszek, Nauczanie religii $w$ szkole, [in:] Wokót katechezy posoborowej, R. Chałupniak, J. Kochel, J. Kostorz, W. Spyka eds., Opole 2004, p. 300; D. Muskus, Szkoła środowiskiem katechetycznym, Kalwaria Zebrzydowska 1999, p. 102.

11 Kongregacja do spraw Duchowieństwa, Dyrektorium Ogólne o Katechizacji, Watykan 1997, no. 73. 
religious education shall be all participants of such lessons, regardless of their religiousness. This is without a doubt an irrefutable argument in favour of organizing religious education within the public education system.

\section{Forming Social Attitudes in Catholic Religious Education}

Countries, which include Catholic religious education within the public education system, expect a direct contribution in the process of upbringing, of basic ethical and moral values ${ }^{12}$ and support in fostering respect for the significance of the local cultural heritage, with a simultaneous openness to values of other cultures ${ }^{13}$. Thus the task expected by the public school to be performed by religion teaching, is to form social attitudes, create an authentic relation not only with God, but also with other people ${ }^{14}$. This includes mainly forming such features as: fairness, altruism and patriotism.

With regards to justice, school religion lesson attempts to shape the attitude of respect for every human being, regardless of their beliefs, religious, national or state affiliations ${ }^{15}$. In this context, heavy emphasis is put on the dignity of every person. Also, the notions of truthfulness and honesty at work, as well as towards the state, come into effect; especially regarding paying taxes. Furthermore, altruism accentuated in religious education, applies to empathy towards every human being, as well as both their material and mental needs ${ }^{16}$. The Catholic Church calls its faithful and all people of good will to practice honesty and love in social life. It is done in a special way during religion classes at school.

$12 \quad$ Minister Edukacji Narodowej, Instrukcja dotyczaca powrotu nauczania religii do szkoty w roku szkolnym 1990/91, [in:] Aspekty prawne nauczania religii rzymskokatolickiej w polskim systemie oświatowym, S. Łabendowicz ed., Radom 2001, p. 8-11; cf. P. Mąkosa. Szkolna lekcja religii istotnym elementem wychowania $w$ szkole, [in:] Wychowanie w szkole: od bezradności ku możliwościom R. Chałupniak, T. Michalewski, E. Smak ed., Opole 2014 p. 351.

13 Sejm Rzeczypospolitej Polskiej. Ustawa z 7 września 1991 roku o systemie oświaty z późniejszymi zmianami, Dz.U. z 1991 no. 56, poz. 458 z późn. zm.

14 K. E. Lawson, Historicalfoundations of Christian education, [in:] Introducing in Christian education: foundations for the twenty-first century, M. J. Anthony ed., Grand Rapids 2011, p. 17; M. Nowak, Edukacyjny potencjat pedagogiki religii bogactwo doświadczenia ludzkiego do przekazania, [in:] Edukacyjny potencjat religii, J. Bagrowicz, J. Horowski ed., Toruń 2012, p. 58.

15 P. Mąkosa, Szkolna lekcja religii istotnym elementem wychowania $w$ szkole, [in:] Wychowanie w szkole: od bezradności ku możliwościom, R. Chałupniak, T. Michalewski, E. Smak eds., Opole 2014, p. 353. 
A lot of time in religious education is devoted to the notion of patriotism, understood as a mature love for ones homeland. As part of Catechetics religious education, such love is examined most often in the context of the fourth commandment of the Decalogue: "Honour thy father and thy mother", and has nothing to do with nationalism or xenophobia ${ }^{17}$. Instead it is all about love towards the land, people, the entire culture existing as part of the state and nation. It is also about fostering national identity and readiness to undertake obligations towards one's homeland, such as the defence of its borders and cultural identity, but also paying taxes and voting in elections ${ }^{18}$.

This type of formation is achieved on the one hand by transferring knowledge about the fundamental principles of social life ${ }^{19}$, and on the other hand, fostering motivation to live by those principles. In other words, it is about a proper formation of conscience, which apart from transferring norms, stresses the motivation to comply therewith. "As it is widely known that knowledge on ethical and moral values, even the most thorough, is in and of itself, insufficient for developing the proper attitudes, as apart from intellect, it is crucial to engage emotion and will"20. In this context, it is worth stressing the undeniable value of religious motivation. Religious faith is one of the strongest factors affecting human behaviour. It could even be claimed that the more religious and engaged in the life of the church the person, the more they are compliant with the principles of social life

Without a doubt, no school subject other than religion, puts so much emphasis on teaching values such as ""responsibility, patriotism, honesty, faithfulness to a value system, sensitivity to the needs of others, truthfulness, tolerance, loyalty, courage, cooperation, engagement in social and political matters, justice, and lawfulness" 21 . Thus, every state, even extremely secular, must consider the benefits from shaping such attitudes, which constitute a foundation for social order.

$17 \quad$ P. Tomasik, Religia $w$ dialogu z edukacja, Warszawa 2004, p. 335.

18 Por. A. Zellma, Wychowanie patriotyczne wspótczesnej młodzieży polskiej w szkolnym nauczaniu religii, „Studia Warmińskie” 40 (2003), p. 189; P. Mąkosa. Szkolna lekcja religii istotnym elementem wychowania $w$ szkole, p. 353.

19 P. Mąkosa. Szkolna lekcja religii istotnym elementem wychowania $w$ szkole, p. 353 .

$20 \quad$ Ibidem, p. 354.

$21 \quad$ P. Tomasik, Religia $w$ dialogu z edukacja, p. 343. 


\section{Catholic Religious Education as Assistance in Finding the Meaning of Life}

In economically developed societies, there is pressure in social life to mainly emphasize practical values, which can directly contribute to their material development. This kind of pressure is also exerted on educational institutions. Society's belief that only knowledge and technical skills have future, and humanist competencies are unnecessary, results in emphasizing technical subjects from the earliest stages of education. This may give rise to reasonable concerns that such an approach corries serious consequences. Of course, no one is negating the fact that technical competence is extremely important in the contemporary world. The problem is that sans a deep humanist education, future societies shall consist of perhaps brilliant IT engineers, but such, who understand nothing about the surrounding world or themselves. Consequently, people who will not find an answer to the basic question about the sense of their own life will not find a deep and permanent happiness. They will be miserable, and, in extreme cases, take their own lives. This is not solely a pessimistic vision of the far future, there are many contemporary examples confirming these theses. It is a fact that more and more people are unable to find themselves in today's world and look for different ways to escape therefrom.

The state is obliged to assist its citizens in developing a mature personality, and thus indirectly also in finding the sense of life and solving problems of existential nature, as it is obvious that finding the sense of one's existence "is the condition necessary for proper development, and indispensable for proper functioning"22. It is clear that religious education is indispensable in performing this task. It helps to create a coherent, objective image of man and the world, including in it religious aspects. Consequently, religious education helps to answer questions about the meaning of life, science, work, suffering, and death. Unlike any other subject it provides support "in borderline situations, where individuals are unable to help themselves" ${ }^{23}$. Thus, religion and religious education help the individual to overcome existential anxiety and find joy in $\operatorname{life}^{24}$. It does not mean that religion is the only source of sense, but it is a deep catalyst thereof. Thus, it is

$\overline{22}$ J. Michalski, Religijność osoby a ksztattowanie poczucia sensu życia, [in:] Edukacyjny potencjat religii, J. Bagrowicz, J. Horowski eds., Toruń 2012, p. 102.

$23 \quad$ Z. Marek, Religia. Pomoc czy zagrożenie dla edukacji? Kraków 2014, p. 129.

24 M. Mendyk, Edukacja religijna integralna częścia wychowania, [in:] Wychowanie w szkole: Od bezradności ku możliwościom, R. Chałupniak, T. Michalewski, E. Smak eds., Opole 2014, p. 144-145. 
in the best interest of the state to organize religious education within the public education system.

\section{Conclusions}

In many countries, state education systems are hostile towards any religion and thus to religious education. At the same time, however, in many other countries, confessional Catholic religious education is conducted within the public school system. The discussion on importance of including religious education in the state-run educational system includes on the one hand arguments on the separation of Church and state, as well as the different ways of understanding of faith and science. On the other hand, however, it is said that teaching religion in schools, contributes to realizing the educational goals, and its removal would be anti-pedagogical ${ }^{25}$. This article attempts to show the extra-religious functions of religious education activity and give arguments for its presence in the state-run educational systems. In other words, motives have been presented, for which a secular state legally separate from the Church, should organize religious education, also in its confessional scope.

The following deliberations indicate three groups of such arguments. The first concerned the transfer of objective knowledge, which simply cannot be fragmented, and more importantly divided into opposing general and religious categories. It was indicated that it is in the best interest of the state to allow such religious education, which will enhance incorporating religious knowledge within the entirety of knowledge possessed by man. Such an approach will also help to build a uniform and coherent world image, free from harmful divisions. The second argument concerned fostering social attitudes i.e. fairness, altruism and patriotism. It was indicated that this aspect is all about forming a mature and righteous conscience ${ }^{26}$. In this process, apart from the transfer of the proper content, the motivational quality of religion was also indicated. Clearly, it is one of the strongest factors motivating people to act ${ }^{27}$. There is even a specific scientific research

$25 \quad$ W. Cichosz, Możliwości dialogu wychowania chrześcijańskiego ze wspótczesna edukacja polska, Pelplin 2013, p. 314-315.

Z. Marek, Religia. Pomoc czy zagrożenie dla edukacji?, p. 129.

27 Por. J. Kula-Lic, Religijność człowieka $w$ procesie psychospołecznego rozwoju, „Pedagogika Katolicka” 2 (2010) no. 7, p. 158-163. 
proving the connection between altruism and religiousness ${ }^{28}$. Anyhow, it is understandable, as Christianity in its essence is a call to serve other people individually and the society as a whole ${ }^{29}$. The last group of arguments analysed herein, were issues related to helping to find meaning in life. It was indicated that an undeniable value of religious education, giving a person strong justification for their own existence ${ }^{30}$, without which it would be very difficult to live, and even more difficult to contribute to development of the world.

This short example is sufficient to show that a successful life of single individuals and entire societies, which is the main goal of education, depends not only on gaining technical knowledge, but, first and foremost, on shaping attitudes that will allow to find a sense of life and form social attitudes. Without religious education achieving these goals is extremely difficult, and sometimes impossible. Therefore, it is necessary to put in every effort to ensure that teaching religion remained part of the public education system. It is necessary to understand that "religious education is not in opposition to the idea of general education" and it should not be "separated from regular pedagogical activities", as it is "rooted in the holistic development of human personality" In the end however, it is worth emphasizing that providing religious education from the Church alone, does not yield the expected results. Interaction is necessary, of all the educational entities, particularly, family, the Church, and school ${ }^{32}$. Each of these entities has various tasks, but a common purpose - the education of $\operatorname{man}^{33}$.

28 J. Śliwak, Altruizm a religijność człowieka - badania empiryczne, „Roczniki Filozoficzne” 41(1993), no. 4, p.41-52; J. Śliwak, M. Szafrańska, Poziomaltruizmu a przeżywane relacje religijne do Boga, [in:] Postawy wobec religii. Psychologiczne uwarunkowania i konsekwencje, T. Doktór, K. Franczak eds., Warszawa 2000, p. 161-185.

Cf. Z. Marek, Religia. Pomoc czy zagrożenie dla edukacji?, p. 131.

Ibidem, p. 153.

G. Hansemann, Wychowanie religijne, Warszawa 1988, p. 16; Cf. W. Osial, Misja wychowawcza lekcji religii w szkole, „Warszawskie Studia Teologiczne” 25 (2012), no. 2, p. 269-280; Cf. R. Chałupniak, Religia w szkole czy poza szkota?, „Pedagogia Christiana”, 15 (2012), no. 1, p. 167.

Z. Marek, Religia. Pomoc czy zagrożenie dla edukacji?, p. 163; J. Makselon, Człowiek jako istota religijna, [in:] Psychologia dla teologów, idem ed., Kraków 1990, p. 260; W. Cichosz, Pedagogia wiary we wspótczesnej szkole katolickiej, Warszawa 2010, p. 191-203.

33 W. Cichosz, Możliwości dialogu wychowania chrześcijańskiego ze współczesna edukacja polska, p. 117. 


\section{SZKOKA PAŃSTWOWA JAKO PODMIOT KATOLICKIEJ EDUKACJI RELIGIJNEJ?}

W wielu krajach świata edukacja religijna odbywa się w ramach państwowego systemu oświaty. Jednocześnie toczy się dyskusja nad zasadnością takiego rozwiązania. Coraz częściej pojawiają się głosy wzywające do usunięcia nauczania religii z państwowej szkoły. Szczególna presja wywierana jest na konfesyjny model edukacji religijnej, w którym przedmiotem nauczania religii są prawdy wiary, liturgia, zasady moralne jednej wspólnoty wyznaniowej. W tym artykule podjęto polemikę z tymi opiniami i ukazano argumenty przemawiające za obecnością katolickiej edukacji religijnej w szkole publicznej. Zastosowana argumentacja dotyczyła przede wszystkim pozareligijnych funkcji, jakie pełni nauczanie religii. Analizie poddano przekaz obiektywnej wiedzy, formowanie postaw społecznych oraz pomoc w odnalezieniu sensu życia. Wykazano, że choćby z tych względów, katolicka edukacja religijna powinna mieć miejsce w państwowym systemie oświaty.

Słowa kluczowe: edukacja religijna, nauczanie religii, religia w państwowym systemie oświaty.

\section{Bibliography:}

1. Chałupniak R., Religia w szkole czy poza szkota?, „Pedagogia Christiana”, 15 (2012), no. 1, p. 163-178.

2. Chałupniak R., Konfesyjność nauczania religii. Zarys problematyki. „Paedagogia Christiana" 3:2000 no. 2(6), p. 31-51.

3. Chałupniak R., Wychowanie religijne w szkotach europejskich, [in:] J. Stala ed., Wybrane zagadnienia z katechetyki, Tarnów 2003, p. 175-201.

4. Cichosz W., Możliwości dialogu wychowania chrześcijańskiego ze wspótczesna edukacja polska, Pelplin 2013.

5. Cichosz W., Pedagogia wiary we wspótczesnej szkole katolickiej, Warszawa 2010.

6. Hansemann G., Wychowanie religijne, Warszawa 1988.

7. Jan Paweł II, Adhortacja apostolska „Catechesi tradendae”, Watykan 1979.

8. Katechizm Kościoła Katolickiego, Watykan 1992.

9. Komisja Wychowania Katolickiego Konferencji Episkopatu Polski, Program Nauczania Religii Rzymskokatolickiej w Przedszkolach i Szkotach, Kraków 2010.

10. Konferencja Episkopatu Polski, Podstawa Programowa Katechezy, Kraków 2010.

11. Kongregacja do spraw Duchowieństwa, Dyrektorium Ogólne o Katechizacji, Watykan 1997.

12. Kula-Lic J., Religijność człowieka w procesie psychospołecznego rozwoju, „Pedagogika Katolicka” 2 (2010) no. 7, p. 158-163. 
13. Lange G. Konfesyjna nauka religii w publicznej szkole zsekularyzowanego społeczeństwa, „Analecta Cracoviensia” 23:1991, p. 239-251.

14. Lawson K. E., Historical foundations of Christian education, [in:] Introducting Christian education: foundations for the twenty-first century, M. J. Anthony ed., Grand Rapids 2011.

15. Makselon J., Człowiek jako istota religijna, [in:] Psychologia dla teologów, idem ed., Kraków 1990, p. 255-314.

16. Marek Z., Religia. Pomoc czy zagrożenie dla edukacji?, Kraków 2014.

17. Mąkosa M., Szkolna lekcja religii istotnym elementem wychowania w szkole, [in:] Wychowanie w szkole: od bezradności ku możliwościom, R. Chałupniak, T. Michalewski, E. Smak eds., Opole 2014, p. 351-361.

18. Mąkosa P., Confessional and catechetical nature of religious education in Poland, "The Person and the Challenges", Volume 5 (2015) no. 2, p. 53-66.

19. Mąkosa P., Wspótczesne ujęcia nauczania religii $w$ europejskim szkolnictwie publicznym, "Roczniki Pastoralno-Katechetyczne", 3 (58):2011, p. 123-136.

20. Mendyk M, Edukacja religijna integralna częścia wychowania, [in:] Wychowanie w szkole: Od bezradności ku możliwościom, R. Chałupniak, T. Michalewski, E. Smak eds., Opole 2014, p. 141-146.

21. Michalski J., Religijność osoby a ksztattowanie poczucia sensu życia, [in:] Edukacyjny potencjat religii, J. Bagrowicz, J. Horowski eds., Toruń 2012, p. 79-104.

22. Minister Edukacji Narodowej, Instrukcja dotyczaca powrotu nauczania religii do szkoty $w$ roku szkolnym 1990/91, [in:] Aspekty prawne nauczania religii rzymskokatolickiej $w$ polskim systemie oświatowym, S. Łabendowicz ed., Radom 2001, p. 8-11.

23. Misiaszek K., Nauczanie religii w szkole, [in:] Wokót katechezy posoborowej, R. Chałupniak, J. Kochel, J. Kostorz, W. Spyka eds., Opole 2004, p. 299-302.

24. Muskus D., Szkoła środowiskiem katechetycznym, Kalwaria Zebrzydowska 1999.

25. Nosowski Z., Lekcje religii $w$ szkołach publicznych państw europejskich, [in:] Szkoła czy parafia? Nauka religii $w$ szkole $w$ świetle badań socjologicznych, K. Kiciński, K. Koseła, W. Pawlik eds., Kraków 1995, p. 11-15.

26. Nowak M. Edukacyjny potencjał pedagogiki religi-bogactwo doświadczenia ludzkiego do przekazania, [in:] Edukacyjny potencjat religii, J. Bagrowicz, J. Horowski ed., Toruń 2012, p. 53-78.

27. Osial W., Misja wychowawcza lekcji religii w szkole, ,Warszawskie Studia Teologiczne" 25 (2012), no. 2, p. 269-280.

28. Sejm Rzeczypospolitej Polskiej, Ustawa z 7 września 1991 roku o systemie oświaty z późniejszymi zmianami, Dz.U. z 1991 no. 56, poz. 458 z późn. zm.

29. Śliwak J, Szafrańska M., Poziom altruizmu a przeżywane relacje religijne do Boga, [in:] Postawy wobec religii. Psychologiczne uwarunkowania $i$ konsekwencje, T. Doktór, K. Franczak eds., Warszawa 2000, p. 161-185.

30. Śliwak J., Altruizm a religijność człowieka - badania empiryczne, „Roczniki Filozoficzne" 41 (1993), no. 4, p. 41-52.

31. Tomasik P., Religia $w$ dialogu z edukacja, Warszawa 2004.

32. Zellma A., Wychowanie patriotyczne wspótczesnej młodzieży polskiej w szkolnym nauczaniu religii, „Studia Warmińskie” 40 (2003), p. 183-197. 